\title{
Digestion of rumen bacteria in vitro
}

\author{
BY R. J. WALLACE \\ Rowett Research Institute, Bucksburn, Aberdeen AB2 9SB, Scotland
}

(Received 22 February 1982-Accepted 22 July 1982)

\begin{abstract}
1. A pepsin + pancreatin method was used to assess the digestibility of pure cultures of rumen bacteria and mixed bacteria prepared from rumen fluid.

2. Individual species of Gram-negative rumen bacteria were highly digestible, whereas Gram-positive species, especially cocci, were more resistant to digestion.

3. A similar difference was observed microscopically with mixed rumen bacteria, but the influence of the relative proportions of Gram-positive and Gram-negative bacteria on the digestibility of bacterial protein in rumen fluid was small.
\end{abstract}

The importance of microbial protein derived from rumen fermentation in the over-all protein metabolism in ruminants has been known for many years. The most recent technical review (Agricultural Research Council, 1980) dealt with many factors which affect microbial productivity in the rumen, and it acknowledged that different sources of dietary protein, if they escape degradation in the rumen, may be absorbed to different extents in the small intestine. However, no distinction was made between different diets regarding the availability of microbial protein. Pounden et al. (1950) made microscopic observations of digesta obtained from different sites in the digestive tract of cattle, and found that some distinctive organisms seemed to survive into the intestines, while others did not pass the abomasum. Later studies with pure cultures in vitro confirmed that different species of rumen bacteria varied in their susceptibility to digestion (Bergen et al. 1967), but the differences were in general not great, and no pattern was found. Hoogenraad $e t$ al. (1970) injected whole cells and cell fractions from ${ }^{14} \mathrm{C}$-labelled Escherichia coli, a Gram-negative bacterium, and Bacillus subtilis, a Gram-positive bacterium, into the abomasum of sheep and concluded from the fate of radioactivity from these non-rumen bacteria that both were extensively digested. Recently, however, Midtvedt \& Gustafsson (1981) found that Gram-positive bacteria, a category not examined by Bergen et al. (1967), varied in their resistance to digestion in germ-free rats, while Gram-negative bacteria were digested completely.

In the present paper, the digestion of Gram-positive bacteria isolated from the rumen is compared with Gram-negative organisms as determined by a pepsin + pancreatin digestion. The digestion of similar organisms in mixed rumen bacteria prepared from rumen fluid was also examined. The findings indicate that the proportions of Gram-positive and Gram-negative bacteria in rumen fluid may influence the nutritive value of the microbial protein leaving the rumen.

\section{MATERIALS AND METHODS}

\section{Rumen bacteria}

Most of the bacteria used in these experiments were isolated at the Rowett Research Institute. Bacteroides succinogenes $\mathbf{S} 85$ was a gift from M. P. Bryant, Butyrivibrio fibrisolvens NOR 37 was obtained from M. J. Latham, and Eubacterium ruminantium 2388 was obtained from the National Collection of Dairy Organisms, National Institute for Research in Dairying, Reading. Cultures were prepared using anaerobic techniques described by Bryant (1972). One loopful of stock culture was used to inoculate $7 \mathrm{ml}$ medium l (Kurihara et al. 
1968), which contained $20 \%$ clarified rumen fluid, and the cultures were grown overnight at $39^{\circ}$. The overnight cultures were centrifuged $\left(27000 \mathrm{~g}, 4^{\circ}, 10 \mathrm{~min}\right)$, resuspended in distilled water and centrifuged once more. The pellet was resuspended in $3 \mathrm{ml}$ distilled water.

\section{Bacterial fraction from rumen fluid}

Rumen fluid was taken from sheep and steers via a rumen cannula or by stomach tube, and was strained through four layers of muslin. Strained rumen fluid $(1 \mathrm{ml})$ was added to $4 \mathrm{ml}$ distilled water. Protozoa and large bacteria were removed by centrifugation $(120 \mathrm{~g}$, $\left.4^{\circ}, 5 \mathrm{~min}\right)$, then the small bacteria were harvested $\left(27000 \mathrm{~g}, 4^{\circ}, 10 \mathrm{~min}\right)$ and resuspended in $5 \mathrm{ml}$ distilled water.

\section{Pepsin + pancreatin digestion}

The method used was based on that developed by Akeson \& Stahmann (1964) for the evaluation of the biological value of dietary protein. Bacterial suspension $(1 \mathrm{ml})$ was added to $1 \mathrm{ml} \mathrm{0.2} \mathrm{m}$-hydrochloric acid containing $0.2 \mathrm{mg}$ pepsin (EC 3.4.23.1; Sigma, Poole, Dorset $) / \mathrm{ml}$ and was incubated at $39^{\circ}$ for $3 \mathrm{~h}$. Undigested bacteria were harvested by centrifugation $\left(27000 \mathrm{~g}, 4^{\circ}, 10 \mathrm{~min}\right)$. This pellet was resuspended in $5 \mathrm{ml} 50 \mathrm{~mm}$-potassium phosphate buffer, $\mathrm{pH} 8 \cdot 0$, and centrifuged again. The pellet was resuspended in $5 \mathrm{ml}$ $50 \mathrm{~mm}$-buffer containing $0.05 \mathrm{mg}$ thimerosal (Sigma) $/ \mathrm{ml}$ and $0.13 \mathrm{mg}$ pancreatin (Sigma) $/ \mathrm{ml}$. This mixture was incubated for $24 \mathrm{~h}$ at $39^{\circ}$, then centrifuged $\left(27000 \mathrm{~g}, 4^{\circ}\right.$, $10 \mathrm{~min}$ ) and the pellet was resuspended in distilled water for turbidimetric and protein analyses.

\section{Analyses}

Bacterial suspensions were diluted with distilled water to give a turbidity of $<0.5$ at $625 \mathrm{~nm}$ in a $10 \mathrm{~mm}$ path-length cuvette in a double-beam, u.v. spectrophotometer (CE595; Cecil Instruments Ltd., Cambridge). Protein in bacterial pellets was measured using the Folin reagent (Herbert et al. 1971) and hydrolysed protein was assayed by a similar method (Lowry et al. 1951). Films of bacteria were stained by Lillie's (1928) modification of Gram's method. Representative microscopic fields, at $\times 1000$ magnification, were scanned to determine the relative numbers of Gram-positive and Gram-negative organisms. A minimum of 200 bacteria were counted for each sample.

\section{RESULTS}

Differences in the digestion of pure cultures of rumen bacteria were obvious visually from the turbidity of the suspensions, and spectrophotometric turbidity readings (Table 1) indicated that Gram-negative species were digested more extensively than Gram-positive species. All bacteria lost some turbidity during a control incubation done in the absence of pepsin and pancreatin, but the turbidities of suspensions of the Gram-negative Bacteroides, Butyrivibrio, Megasphaera, Selenomonas and Veillonella species were decreased far more than that of Gram-positive Lactobacillus, Staphylococcus and Streptococcus species following incubation with the enzyme preparations (Table 1). Eubacterium and Ruminococcus species, although usually classified as Gram-positive, stained Gram-negative in the stationary-phase cultures used in these experiments. They were also extensively digested, like the true Gram-negative organisms.

Similar differences in digestibility of the individual organisms were apparent from comparisons of particulate (i.e. sedimented at $27000 \mathrm{~g}$ ) protein concentrations before and after digestion and in control incubations with no added enzymes (Table 2). Gram-negative bacteria had apparent protein digestibilities in excess of 0.8 and usually greater than 0.9 , whereas the digestibility of the Gram-positive bacteria, especially the cocci, was much less, at a mean of 0.39 for the five species tested. Estimations of the amino acids released by 
Table 1. Influence of pepsin + pancreatin digestion on turbidity of pure cultures of rumen bacteria

(Stationary-phase rumen bacteria, grown in the rumen fluid-containing medium 1 (Kurihara $e t$ al. 1968), were subjected to a pepsin then a pancreatin digestion as used by Akeson \& Stahmann (1964) to evaluate protein quality)

\begin{tabular}{|c|c|c|c|c|}
\hline \multirow[b]{2}{*}{ Species } & \multirow[b]{2}{*}{$\begin{array}{c}\text { Gram's } \\
\text { stain }\end{array}$} & \multicolumn{3}{|c|}{ Turbidity* } \\
\hline & & $\begin{array}{c}\text { Before } \\
\text { incubation }\end{array}$ & $\begin{array}{c}\text { No } \\
\text { enzymes }\end{array}$ & $\begin{array}{l}\text { Pepsin }+ \\
\text { pancreatin }\end{array}$ \\
\hline Bacteroides ruminicola 223 & - & $4 \cdot 18$ & $3 \cdot 11$ & $0 \cdot 17$ \\
\hline B. succinogenes $\mathbf{S} 85$ & - & 0.92 & 0.74 & 0.04 \\
\hline Butyrivibrio fibrisolvens NOR 37 & - & 1.68 & 1.09 & 0.25 \\
\hline B. fibrisolvens B834 & - & 1.63 & $1 \cdot 00$ & 0.09 \\
\hline Eubacterium ruminantium 2388 & $+1-$ & $1 \cdot 30$ & 0.94 & $0 \cdot 14$ \\
\hline Lactobacillus casei $\mathrm{LB} 17$ & + & $1 \cdot 20$ & 0.97 & 0.46 \\
\hline Megasphaera elsdenii $\mathrm{JI}$ & - & $4 \cdot 30$ & $3 \cdot 34$ & 0.50 \\
\hline Ruminococcus albus $\mathrm{SY} 3$ & - & 1.91 & 1.04 & 0.06 \\
\hline R. flavefaciens 007 & $+1-$ & 0.62 & 0.41 & 0.05 \\
\hline Selenomonas ruminantium WPL $151 / 1$ & - & 3.48 & $2 \cdot 07$ & 0.43 \\
\hline Staphylococcus $3588 / 2$ & + & $1 \cdot 50$ & $1 \cdot 10$ & $1 \cdot 03$ \\
\hline Streptococcus bovis no. 26 & + & 1.91 & 1.85 & 1.65 \\
\hline S. bovis $45 \mathrm{~S} 1$ & + & $2 \cdot 62$ & $2 \cdot 13$ & 1.98 \\
\hline S. faecium SFDC & + & $2 \cdot 22$ & $1 \cdot 51$ & $1 \cdot 41$ \\
\hline Veillonella alcalescens 692 & - & 0.93 & $0 \cdot 55$ & 0.09 \\
\hline
\end{tabular}

* Bacterial suspensions were diluted to an absorbance of $<0.5$ at $625 \mathrm{~nm}$ for the measurement of turbidity.

each of the enzyme digestions showed that most protein was released at the pepsin step, and again considerable quantities of protein were lost from some species simply by the incubation procedure (Table 2 ). The fact that live bacteria, most likely with some amino acid degrading activity, were used in these experiments probably accounts for the incomplete recovery of protein seen in most of the incubations.

Rumen fluid was obtained by stomach tube or via a rumen cannula from steers and sheep receiving a variety of diets, and the bacterial suspensions prepared from this material were subjected to the same digestion as the pure cultures. Microscopic examination of Gram films showed that the proportion of bacteria in rumen fluid which were Gram-positive was quite variable but highest in steers receiving a semi-synthetic diet (Table 3). Gram-negative bacteria were decreased greatly in number by the digestion, and most of the recognizable bacteria were Gram-positive. Much Gram-negative debris was present after the digestion, and some Gram-positive organisms were irregularly stained, so that a true count of the relative proportions of the different types of bacteria in the digested material was not possible. Clumping of bacteria on a microscopic scale following the repeated centrifugation procedures exacerbated these problems. There was a trend towards an increased proportion of the bacterial protein escaping digestion as the proportion of Gram-positive organisms in the original suspension increased, but the effect on the over-all protein digestibility was small (Fig. 1). The best-fitting straight line indicated that, if the percentage of Gram-positive bacteria increased from 5 to $30 \%$ (approximately the range observed here), the digestibility of the bacterial protein would decrease only from 0.95 to 0.92 . 
R. J. WALLACE

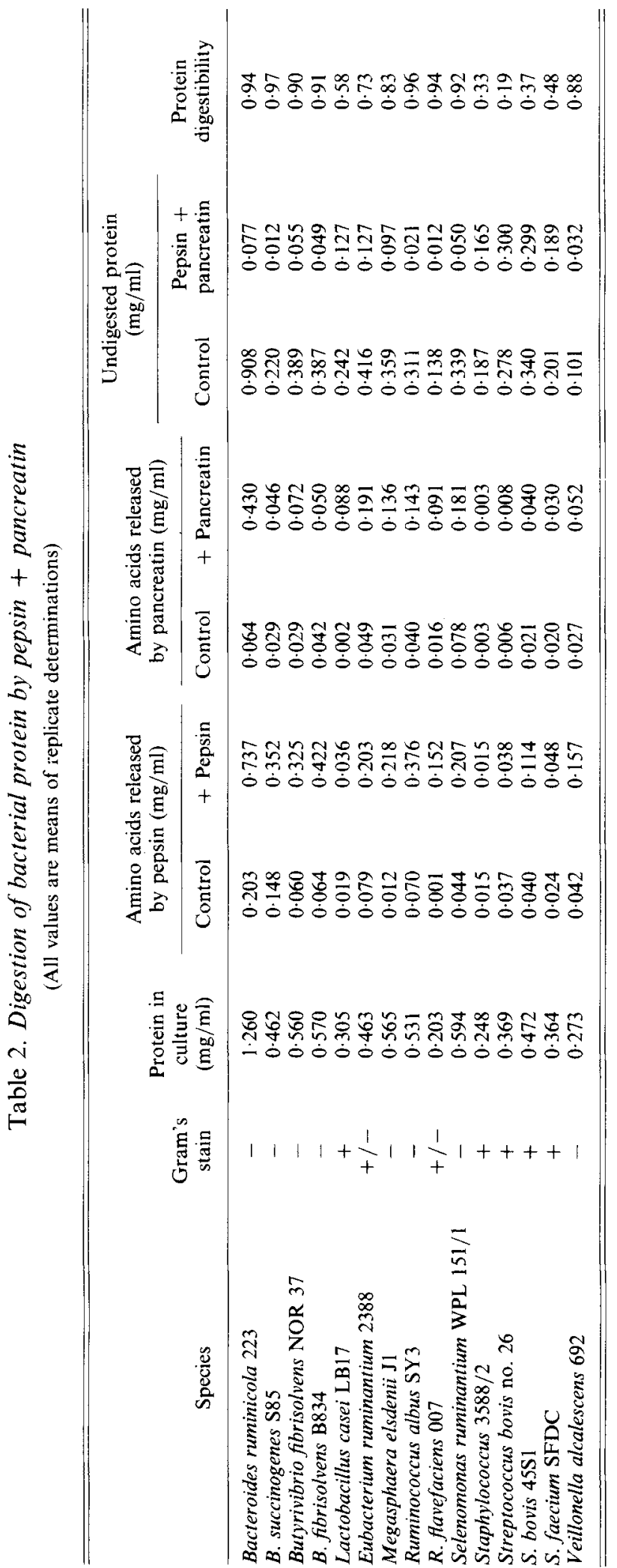


Table 3. Digestion of mixed rumen bacteria by pepsin + pancreatin

\begin{tabular}{|c|c|c|c|c|}
\hline Animal & $\begin{array}{l}\text { Type of } \\
\text { sample }\end{array}$ & $\begin{array}{c}\text { Diet } \\
(\mathrm{g} / \mathrm{kg})\end{array}$ & $\begin{array}{l}\text { Gram- } \\
\text { positive } \\
\text { bacteria } \\
(\%)\end{array}$ & $\begin{array}{c}\text { Particulate } \\
\text { protein remaining } \\
\text { after digestion } \\
(\%)\end{array}$ \\
\hline \multicolumn{5}{|l|}{ Steer no. } \\
\hline 570 & $\mathbf{S}$ & & $21 \cdot 0$ & $4 \cdot 1$ \\
\hline 584 & $\mathbf{S}$ & 300 Oat husk, 200 dried skimmed milk, & $15 \cdot 8$ & $10 \cdot 7$ \\
\hline 583 & $\mathbf{S}$ & 200 starch, 130 sugar, 60 glucose, & $16 \cdot 7$ & $7 \cdot 5$ \\
\hline 581 & $\mathrm{~S}$ & 40 arachis oil, 30 urea, ad lib. & $26 \cdot 9$ & $6 \cdot 0$ \\
\hline 585 & $S$ & & $28 \cdot 4$ & $9 \cdot 7$ \\
\hline 117 & $\mathrm{C}$ & Mixed diet, containing swedes, hay, | & $12 \cdot 3$ & $8 \cdot 0$ \\
\hline 116 & $\mathrm{C}$ & dried grass, barley, ad lib. & $11 \cdot 4$ & $6 \cdot 8$ \\
\hline \multicolumn{5}{|l|}{ Sheep no. } \\
\hline 5140 & $\mathrm{C}$ & 670 barley, 330 hay four times/d & 8.9 & $5 \cdot 8$ \\
\hline 5144 & $\mathrm{C}$ & 600 concentrate, 400 hay twice $/ d$ & $11 \cdot 3$ & $5 \cdot 2$ \\
\hline 5114 & $\mathrm{C}$ & 600 concentrate, 400 hay twice $/ d$ & $7 \cdot 6$ & $4 \cdot 3$ \\
\hline 5094 & $\mathrm{C}$ & 600 concentrate, 400 hay twice $/ d$ & 6.9 & 3.9 \\
\hline 2100 & $\mathrm{C}$ & 670 barley, 330 hay twice/d & 7.5 & $6 \cdot 2$ \\
\hline 914 & $\mathrm{C}$ & 670 dried grass, 330 concentrate twice $/ \mathrm{d}$ & $7 \cdot 9$ & $5 \cdot 6$ \\
\hline 4381 & $\mathrm{C}$ & 670 hay, 330 barley twice $/ \mathrm{d}$ & $7 \cdot 0$ & $5 \cdot 3$ \\
\hline 356 & $\mathbf{S}$ & 670 dried grass, 330 concentrate twice/d & $11 \cdot 9$ & $4 \cdot 2$ \\
\hline 341 & $\mathbf{S}$ & 670 dried grass, 330 concentrate twice/d & $4 \cdot 3$ & 5.9 \\
\hline 2610 & $\mathrm{C}$ & 670 barley, 330 hay ad lib. & $5 \cdot 7$ & 3.9 \\
\hline 4064 & $\mathrm{C}$ & Hay ad lib. & $5 \cdot 3$ & $3 \cdot 8$ \\
\hline 5173 & $\mathrm{C}$ & Hay ad lib. & $7 \cdot 2$ & 3.6 \\
\hline 5082 & $\mathrm{C}$ & 670 hay, 330 barley twice/d & $9 \cdot \overline{5}$ & $5 \cdot 7$ \\
\hline
\end{tabular}

$\mathrm{S}$, samples taken by stomach tube; $\mathrm{C}$, samples taken via rumen cannula.

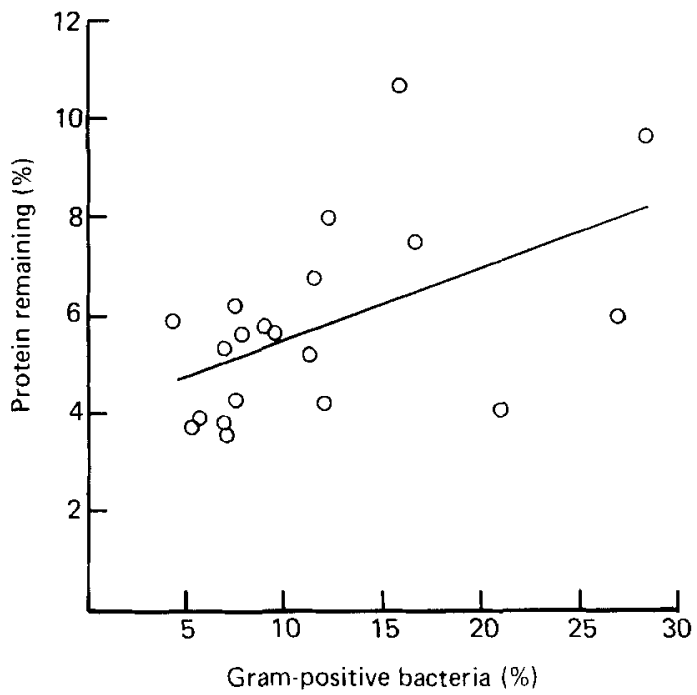

Fig. 1. Influence of the percentage of rumen bacteria which are Gram-positive on the digestion of bacterial protein by pepsin + pancreatin. 


\section{DISCUSSION}

One of the first steps in classifying pure cultures of bacteria is to determine whether they retain the basic dye crystal violet when they are washed with ethanol. Those organisms which do are classified Gram-positive, those which do not, Gram-negative. The chemical basis for this difference is not known precisely, but there are major ultrastructural and chemical differences between the two types (Braun \& Hantke, 1974; Costerton et al. 1974; Lugtenberg, 1981). Cell walls of Gram-positive bacteria are simple in structure, while Gram-negative bacteria have several distinct surface layers. Chemically, both contain peptidoglycan and polysaccharides, although Gram-positive bacteria contain much more of the former than do Gram-negative bacteria. Gram-positive cell walls contain little or no lipid or protein, whereas these are major constituents of Gram-negative walls. Conversely, Gram-positive bacteria have large quantities of teichoic and teichuronic acids which Gram-negative organisms have not. It is, therefore, perhaps to be expected that these two classes of bacteria might differ in their susceptibility to hydrolytic enzymes, including those of the digestive tract.

The results presented in this paper show that there is indeed a distinction between Gram-positive and Gram-negative species of rumen bacteria, when subjected to a pepsin + pancreatin digestion in vitro (Tables 1 and 2). Gram-negative bacteria, with a high content of protein in their cell walls, were much more susceptible to this essentially proteolytic digestion. In terms of the digestibility of protein, Gram-negative bacteria were, on average, $92 \%$ digestible, while the corresponding value of Gram-positive bacteria was $39 \%$ (Table 2). The difference was even more marked when turbidities of bacterial suspensions were compared (Table 1), indicating that the cellular integrity of Gram-positive bacteria was affected little despite the extent of protein digestion observed, and that Gram-negative bacteria disintegrated almost totally as a result of the digestion.

Not all species of rumen bacteria can be classified as Gram-positive or Gram-negative without further qualification. Butyrivibrio fibrisolvens, for example, always stains Gramnegative, yet morphologically appears Gram-positive in electron micrographs (Cheng \& Costerton, 1977) and is known to contain teichoic acids (Sharpe et al. 1975; Hewett et al. 1976). Ruminococcus albus and $R$. flavefaciens, on the other hand, are grouped with Gram-positive cocci (Holdeman et al. 1977) despite the fact that $R$. albus always appears Gram-negative according to the staining procedure and only rarely does $R$. flavefaciens appear truly Gram-positive. Similarly, Eubacterium ruminantium is classified as being Gram-positive, but stained Gram-negative in the overnight cultures used in these experiments. Indeed, all of these bacteria with doubtful or variable status stained Gram-negative, and were also digested as extensively as other Gram-negative organisms during the pepsin + pancreatin procedure (Tables 1 and 2). Thus the retention of crystal violet in the Gram's stain seems to give a good indication of the digestibility of rumen bacteria. It would be interesting to see whether the digestibility of Gram-variable organisms such as $R$. flavefaciens did in fact depend on the degree of Gram-positive staining produced by different culture conditions.

Bergen et al. (1967) used a similar digestion procedure with rumen bacteria, and found some variation in both the digestibility and the biological value between individual species. No Gram-positive bacteria were used, however, and so their resistance to digestion was not observed.

The conclusions from experiments with pure cultures (Tables 1 and 2) applied equally well to mixed rumen bacteria prepared from rumen fluid (Table 3). Again, Gram-positive bacteria survived digestion better than Gram-negative bacteria (although this does not imply that they remained viable, which was not tested here). This pattern is in accord with the 
early microscopic findings of Pounden et al. (1950) who observed that distinctive large bacteria (not included in the present survey) varied markedly in their survival in the digestive tract, and with the similar observations in gnotobiotic rats with Gram-positive and Gram-negative small bacteria (Midtvedt \& Gustafsson, 1981).

It is not clear why Bacillus subtilis, a non-rumen Gram-positive bacterium, should have proved as digestible in sheep as the Gram-negative Escherichia coli (Hoogenraad et al. 1970) in view of the results obtained here in vitro, where there is a very clear distinction between the two classes in their digestibility (Table 2). It is possible that B. subtilis is one of the more digestible Gram-positive organisms, although this seems unlikely from the results of Midtvedt \& Gustafsson (1981). Other possible causes are that freeze-drying, used by Hoogenraad et al. (1970), alters the digestibility, or that substantial autolysis occurs, or that ill-defined lytic factors in rumen fluid (Jarvis, 1968) may influence digestibility in vivo. Freeze-drying of $S$. bovis $45 \mathrm{~S} 1$ increased the protein digestibility from $37 \%$ (Table 2) to $75-88 \%$ (not shown), indicating that alteration of the digestibility is the most likely cause of this apparent discrepancy.

Gram-positive bacteria are usually the minor component of the rumen bacterial population (Table 3; Hungate, 1966; Bryant, 1970), and so under most circumstances a change in their proportion will have only a minor effect on the digestibility of the microbial protein leaving the rumen (Table 3). The results in Fig. 1 show that there is a trend towards a lower digestibility as the proportion of Gram-positive organisms increases, but this is clearly subject to a great deal of variability. This is to be expected, since factors other than the proportion of Gram-positive bacteria may be important in determining digestibility. Furthermore, numerical proportion is inevitably a poor indicator of the relative proportions of the different types in terms of bacterial protein. The great variation in size which bacteria can display means that small bacteria can increase the number dramatically, with little effect on biomass. For example, the Gram-negative bacteria from steer no. 570 (Table 3) were generally much larger than those from steer no. 584 (Table 3), which had many very small Gram-negative cocci. Thus, although the numerical proportion of Gram-positive bacteria in steer no. 570 was larger than that in steer no. 584, the quantity of Gram-positive biomass was certainly less. Inspection of the coordinates of these determinations in Table 3 and Fig. 1 shows how far both diverge from the majority of the values. The quantity of crystal violet retained or some other measure of the mass rather than number of Gram-positive bacteria would be more likely to give a better relationship with digestibility.

Occasionally, and especially with an unstable or transient rumen fermentation, Grampositive organisms can become more prominent (Eadie \& Mann, 1970; Mann, 1970) and would be expected to influence more significantly the digestibility of microbial protein, thus causing between- and within-animal variability in some experiments. For example, steer no. 570 had $21 \%$ of its bacterial population Gram-positive in this experiment (Table 3), whereas 2 months previously, when the semisynthetic diet was essentially the same, the value had been $47 \%$. Ordinarily, however, only Streptococcus bovis of the resistant Gram-positive bacteria tested here would be frequently isolated from high ( $\times 10^{8}$ and higher) dilutions of rumen fluid from a healthy adult rumen, and the Gram-positive content of rumen bacteria would have a small effect on the digestibility of microbial protein. This is particularly true if the protozoal population is high, and bacterial protein comprises less of the total microbial protein. It should be noted here that bacterial protein in these experiments was measured using the Folin reagent, and so it is a measure of true protein. The digestibility of bacteria in terms of crude protein (nitrogen $\times 6.25$ ) would be lower, as crude protein would include the $\mathrm{N}$ contained in the amino sugars and amino acids of the cell wall peptidoglycans and teichoic acids, which may be only partly digested even in Gram-negative bacteria (Mason \& White, 1971). 
The effects of digestion-resistant Gram-positive bacteria may be more important in other aspects of ruminant nutrition, however. For example, bacterial cell walls are rather like ion-exchange resins and can bind considerable quantities of metal ions. Differences in cell-wall digestion may, therefore, have some consequences in the availability of trace elements to the ruminant. This would be especially true if, as seems possible, some metal ions bind preferentially to the cell walls of Gram-positive bacteria (Jernelov \& Martin, 1975; Beveridge \& Murray, 1980). Then changes in the bacterial population which had a negligible effect on the digestibility of bacterial protein might yet have a major infiuence on the availability of trace metals.

The skilled technical assistance of Mrs Susan Black and Miss Margaret Brammail is gratefully acknowledged, as is the cooperation of Mr W. R. Humphries, Mr N. A. McLeod, Dr E. R. Ørskov and Mr W. Shand in taking samples of rumen fluid. The interest and encouragement given by Mr Humphries contributed significantly to this work.

\section{REFERENCES}

Agricultural Research Council (1980). The Nutrient Requirements of Ruminant Livestock. Slough: Commonwealth Agricultural Bureaux.

Akeson, W. R. \& Stahmann, M. A. (1964). J. Nutr. 83, 257.

Bergen, W. G., Purser, D. B. \& Cline, J. H. (1967). J. Nutr. 92, 357.

Beveridge, T. J. \& Murray, R. G. E. (1980). J. Bact. 141, 876.

Braun, V. \& Hantke, K. (1974). A. Rev. Biochem. 43, 841.

Bryant, M. P. (1970). Am. J. clin. Nutr. 23, 1440.

Bryant, M. P. (1972). Am. J. clin. Nutr. 25, 1324.

Cheng, K.-J. \& Costerton, J. W. (1977). J. Bact. 129, 1506.

Costerton, J. W., Ingram, J. M. \& Cheng, K.-J. (1974). Bact. Rev. 38, 87.

Eadie, J. M. \& Mann, S. O. (1970). In Physiology of Digestion and Metabolism in the Ruminant, p. 335 [A. T. Phillipson, editor]. Newcastle: Oriel Press.

Herbert, D., Phipps, P. J. \& Strange, R. E. (1971). In Methods in Microbiology, vol. 5B, p. 209 [J. R. Norris and D. W. Ribbons, editors]. London: Academic Press.

Hewett, M. J., Wicken, A. J., Knox, K. W. \& Sharpe, M. E. (1976). J. gen. Microbiol. 94, 126.

Holdeman, L. V., Cato, E. P. \& Moore, W. E. C. (1977). Anaerobe Laboratory Manual, 4th edn. Blacksburg, Virginia: Virginia Polytechnic Institute and State University.

Hoogenraad, N. J., Hird, F. J. R., White, R. G. \& Leng, R. A. (1970). Br. J. Nutr. 24, 129.

Hungate, R. E. (1966). The Rumen and its Microbes. London: Academic Press.

Jarvis, B. D. W. (1968). Appl. Microbiol. 16, 714.

Jernelov, A. \& Martin, A. (1975). A. Rev. Microbiol. 29, 61

Kurihara, Y., Eadie, J. M., Hobson, P. N. \& Mann, S. O. (1968). J. gen. Microbiol. 51, 267.

Lillie, R. D. (1928). Arch. Path. 5, 828.

Lowry, O. H., Rnsebrough, N. J., Farr, A. L. \& Randall, R. J. (1951). J. biol. Chem. 193, 265.

Lugtenberg, B. (1981). Trends biochem. Sci. 6, 262.

Mann, S. O. (1970). J. appl. Bact. 33, 403.

Mason, V. C. \& White, F. (1971). J. agric. Sci, Camb. 77, 91.

Midtvedt, T. \& Gustafsson, B. E. (1981). Curr. Microbiol. 6, 13.

Pounden, W. D., Ferguson, L. C. \& Hibbs, J. W. (1950). J. Dairy Sci. 33, 565.

Sharpe, M. E., Brock, J. H. \& Phillips, B. A. (1975). J. gen. Microbiol. 88, 355. 